\title{
The (un)preparation of the judiciary hospital for resocialization: violation of human rights
}

\author{
O (des)preparo do hospital judiciário para a ressocialização: violação de direitos humanos
} La (des)preparación del hospital judicial para la resocialización: violación de los derechos humanos

\author{
Ana Flávia Ferreira de Almeida Santana \\ Maria Odete Pereira ${ }^{1}$ \\ Marília Alves ${ }^{1}$
}

1. Universidade Federal de Minas Gerais.

Belo Horizonte, MG, Brasil.
Corresponding author:

Maria Odete Pereira.

E-mail: m.odetepereira@gmail.com

Submitted on $02 / 13 / 2017$

Accepted on 05/09/2017.

DOI: 10.1590/2177-9465-EAN-2017-0022

\section{Abstract}

Objective: To analyze the hospital's capacity of custody and treatment for resocialization of patients with psychic disorders, under security measure. Methods: An empirical, qualitative, interpretive and cross-sectional study was carried out in a hospita of custody and treatment (HCT) of a city in the southeast region of Minas Gerais, Brazil, with 22 administrative, health e security workers, through an interview with a semi-structured instrument and non-participant observation. Data were submitted to Content Analysis and presented in the categories: the hospital of custody and treatment: therapeutic space, in fact?; the HCT as a place of segregation and punishment; and the in(ability) of the legal mental hospitals for resocialization. Results: Some professionals considered the hospital as a treatment space, while others considered it an instrument of punishment. However the punitive nature of the interventions predominated. From the perspective of the participants, the hospital does not promote the resocialization. Conclusion: In the hospital there are no treatments that attend to the uniqueness of the patients who were under safety measure, therefore, they are not prepared to return to the social life, as it happens in prisons. The institution does not promote the resocialization of the patients.

Keywords: Health Care; Insanity Defense; Patient Rights; Mental Disorders; Nursing.

\section{Resumo}

Objetivo: Analisar a capacidade do hospital de custódia e tratamento para a ressocialização de pacientes com transtornos psíquicos, em medida de segurança. Métodos: Estudo empírico, qualitativo, interpretativo e transversal, desenvolvido em um Hospital de custódia e tratamento de um município da região Sudeste de Minas Gerais, Brasil, com 22 trabalhadores administrativos, da saúde e de segurança, por meio de entrevista com instrumento semiestruturado e observação não participante. Os dados foram submetidos à análise de conteúdo e apresentados nas categorias: o hospital de custódia e tratamento: espaço terapêutico, de fato?; o HCT como lugar de segregação e punição; e a in (capacidade) do manicômio judiciário para a ressocialização. Resultados: Alguns profissionais consideraram o hospital como espaço de tratamento, enquanto outros o consideraram instrumento de punição. No entanto, predominou o caráter punitivo das intervenções. Na perspectiva dos participantes, o hospital não promove a ressocialização. Conclusão: No hospital não há tratamentos que atendam à singularidade dos pacientes que estavam em medida de segurança, portanto, estes não são preparados para retornar ao convívio social assim como ocorre nos presídios. A instituição não investe na ressocialização de seus pacientes.

Palavras-chave: Assistência à Saúde; Defesa por Insanidade; Direitos do Paciente; Transtornos Mentais; Enfermagem.

\section{Resumen}

Objetivo: Analizar la capacidad del hospital de custodia y tratamiento para la resocialización de los pacientes con trastornos mentales en medida de seguridad. Métodos: Estudio empírico, cualitativo, interpretativo y transversal, desarrollado en el Hospital de Custodia y Tratamiento de un municipio del Sudeste de Minas Gerais, Brasil, con 22 trabajadores administrativos, de salud e de seguridad, por medio de entrevista semiestructurada y observación no participante. Los datos fueron sometidos al Análisis de Contenido y presentado en las categorías: Hospital de custodia y tratamiento: espacio terapéutico, de hecho?; EI HCT como espacio de segregación y punición; e in(capacidad) del manicomio judicial para la rehabilitación. Resultados: Algunos profesores consideraron el hospital como espacio de tratamiento, otros, instrumento de punición. Para los participantes, no se promueve una resocialización. Conclusión: No hay hospitales que atiendan a la singularidad de los pacientes en medida de seguridad. La institución no promueve una resocialización de los pacientes.

Palabras clave: Atención a la Salud; Defensa por Insania; Derechos del Paciente; Trastornos Mentales; Enfermería. 


\section{INTRODUCTION}

The Brazilian psychiatric reform, regulated by Law No. 10216 of 2001, redirected the care model to people with mental disorders, determining the deconstruction of the mental hospitals, which maintained patients as institutionalized residents. Hospitals for Custody and Psychiatric Treatment HCPT are the last asylums to be dismantled today, in the legalpolitical and conceptual conjunctures. ${ }^{1}$

The word asylum has its roots in the Greek words "a-" and "sulon", which respectively mean without and right of seizure, therefore a place of refuge. The Brazilian word for mental hospitals, manicômio, has its origin in the Greek words "asylon" and "komêin", which respectively mean madness and heal, from its meaning, it is inferred that the asylum is the institution destined to the treatment of people with mental disorders. ${ }^{2}$

The legal mental hospitals were institutions designed in the nineteenth century to house monomaniacal and degenerate criminals that compromised the functioning of social defense. In this way, the judiciary asymmetries assumed characteristics of prison and mental hospitals. They reveal themselves as hybrid institutions, difficult to define and with contradictory objectives. ${ }^{3}$

In Brazil, the judiciary mental hospitals are structures that integrate and mix functions of hospital and of prison institution. From a juridical point of view, the person with mental disorder, when committing a crime, is not considered to be the author of the act, because it is considered unimpeachable, that is, incapable of distinguishing the unlawful nature of the acts themselves, due to psychic illness. Thus, the law determines the acquittal and application of Security Measure - SM. ${ }^{4}$

After the Brazilian Penal Reform of 1984, the judiciary mental hospitals was renamed. The new denomination "Hospital of Custody and Psychiatric Treatment" - HCPT, certainly was influenced by the movement and principles of the Psychiatric Reform. The mental hospital became a hospital, a place destined to the treatment and the recovery of people, but it did not abandon the interference of the State, that still needed to guard the people admitted there. In addition, the "hospital" was never under the responsibility of the Ministry of Health, but rather of the Ministry of Justice, keeping it excluded from the agenda of public policies on mental health. These are officially criminal institutions that are not necessarily governed by the norms and guidelines of the SUS, so much so that HCTPS do not have hospital beds. ${ }^{1}$

In the perspective of the Brazilian Psychiatric Reform, the deinstitutionalization, re-socialization and psychosocial rehabilitation of people with mental disorders should be promoted by all the professionals involved in care, through intersectoral actions, nurturing foster care, bonding, co-responsibility and autonomy. These must be reinserted in society and have their citizenship fully restored.

In this sense, the question that guided the present study was: does the hospital of custody and treatment in fact manage to promote the resocialization of its patients?
There are few articles that deal with this issue, since between 2006 and 2016, only fourteen articles were published in the Virtual Health Library - BIREME.

Thus, the study is of great social relevance, because of the contribution it brings to professionals and managers who work in this modality of institution, allowing them to rethink their practice; to science, for filling the gap of scientific production in this subject and public policies, for proposing strategies that allow to transform corrective interventions to patients in care, in the broad sense of the word.

Therefore, the objective of this research was to analyze the hospital's capacity of custody and treatment for resocialization of patients.

\section{METHODS}

This is an exploratory, cross-sectional and interpretative study, in the case study modality, having as study scenario the Hospital of Custody and Treatment Jorge Vaz - HCTJV, located in the city of Barbacena, MG. Data were collected between August and September 2014

The case study consists of a research modality that studies events in a real-life context, being understood as the most appropriate design for the investigation of a case, in which its limits are not clearly defined. ${ }^{5}$

The HCT is subordinated to the State Department of Social Defense of the state of Minas Gerais - SDSD. It is considered an institution providing custody and assistance to criminals, with the purpose of assuring hospitalization and psychiatric, therapeutic and re-educational treatment of individuals of both sexes, from the age of 18 , provisional and/or sentenced to comply with security measure aiming the cessation of their dangerousness. The institution has the capacity to receive 219 patients, both men and women, in two buildings that make up the unit, each of which has galleries where the cells are located. ${ }^{2}$

The sample for convenience consisted of 22 health, administrative and security workers, with employment relationship with the HCT, without distinction of type of contract (contracted or effective) or being a judge of Criminal Courts of Penal Execution. These were the eligibility criteria for participation in the study. The data saturation was adopted for the delimitation of the number of participants.

Data were collected through document analysis, interviews and non-participant observation. We used a semi-structured instrument prepared by the authors for the interview, which were recorded in MP4 Player.

In a later stage, the data were transcribed in full and organized in the following phases: pre-analysis; exploitation of the material; treatment of results; inference and interpretation. ${ }^{6}$ The interviews were identified in the text by the letter $\mathrm{E}$, plus the initials of the professional category (NA - Nursing Assistant, SA - Security Agent, SW - Social Worker, N - Nurse, D - Doctor, $P$ - Psychologist) and the interview number, for example: Nursing Assistant 1 (ENA1). 
For the data analysis, Laurence Bardin's Content Analysis Technique was used to find out what lies behind the words in which the author leans on. The categories arose after the inquiring of the guiding questions, being: the Hospital of Custody and Treatment: therapeutic space, in fact?; The HCT as a place of segregation and punishment; The in(ability) of the legal mental hospitals for resocialization.

The project was approved by the Research Ethics Committee (CAAE no 03448812.5.0000.5149) and all the participants signed the Informed Consent Term (TCLE).

\section{RESULTS AND DISCUSSION}

In this section, the data about the clinical and therapeutic practice performed in the HCT will be presented. The authors will analyze if the treatment destined to the patients allows the resocialization of the patients, in the view of the professionals that worked in that institution.

In the first category, the contents of the participants' statements about the mission of the custody hospital were analyzed as a space of care and treatment and, therefore, of resocialization.

\section{The Hospital of Custody and Treatment: therapeutic space, in fact?}

In theory, there was a defense, by some professionals, of the effectiveness of the treatment provided by the HCT. The follow up of the patient during the period of hospitalization and after discharge was highlighted as attribution of the institution.

The professionals highlighted the quality of the treatment offered to the patients during the hospitalization, according to the following speech:

I believe that's it: it's treatment and follow-up. Not only punishment, serving the sentence, has to be treated....] We have a very cool project, which is to treat, to follow-up, even after leaving. I think it has to continue! (ENA1)

The professional reported the objectives of the institution, which would be the treatment and follow-up of patients, inside and outside the walls of the HCT. However, the speech gives the idea that the first goal is punishment. Treatment is a necessary complement to the sentence.

Hospitals of Custody and Psychiatric Treatment are based on notions such as the termination of dangerousness, which applies in the broad sense, encompassing several psychopathological categories, besides being erroneously based on the possibility of "cure" (emphasis by the author) of Psychopathology, which is much questioned in its entirety. ${ }^{7}$

I can observe that many drug users arrive here and as they lose access to the drug, they end up leaving the addiction. For me this is the best quality of HCT. Take the person out of that vulnerability out of here. I see it that way. [...] my criticism regarding the treatment of the patient here in the mental hospitals is positive. You see on television with regard to prisons. They are extremely degrading and we do not see that it here! There is some time when there is some degradation, but this is much more by decision of the patient. It is not external determination, it is a determination of the patient himself. (ESA1)

The professional highlighted the quality of treatment as "compulsory" abstinence, considered beneficial and efficient to 125 drug users hospitalized at the institution, during the period of data collection.

It is perceived in this speech that there is an attempt to suppress publicity of merely punitive character credited to institutions of this nature. In addition, condemnation itself brings to the patient the negative mark of social segregation.

In order to qualify the treatment offered to the patients, the professional used as a parameter the treatment given to inmates of prison units, claiming that the inmates of the HCT received a different treatment. Thus, according to the above statements, for those who were characterized as criminals or as socially undesirable subjects, any and all attention paid to them would suffice. In addition, if there is degradation this is exclusively the responsibility of patients.

The logic of internment and social segregation for the treatment of drug users is defended by various segments of society. This was introduced in Brazil by the movement of mental hygiene and, although dominant, most of the time does not result in therapeutic success. Because they do not privilege subjective issues of the subjects and emphasize prohibitionism and abstinence, they, when leaving the hospital, resume the problematic use of psychoactive substances. ${ }^{8-10}$

The treatment is done precisely for the person to feel that is being treated. The patient feels that he is improving. It's not me that says: - look you're getting better! I see each week when I take them to call the families or a friend. Then you hear in the conversation: "It's fine here. I'm getting better, I'm feeling better. I'm not crying so much". You see their evolution, as in a hospital. (ESW1)

The professional reported a personal perception built up from observations. Direct contact with patients and vigilance, at the time of phone calls to relatives and friends, give them the opportunity to believe in the effectiveness of treatment.

Listening to patients and their telephone conversations, saying that they are being treated and are improving, led the worker to infer that they were satisfied with the treatment received. However, all the visits and hospitalizations performed with the inmates were accompanied by a penitentiary agent, at least. In the name of security the doors of the rooms were never closed. This meant that the patient was monitored during his phone call and therefore had no freedom to make complaints, criticisms and claims. 
Knowing the workers and the mental hospitals gear, should they not question the rules and modus operandi that are imposed in these institutions and which perpetuate themselves as truths? Should they not overcome and break with these postulates? ${ }^{11,12}$

The treatment is good, because he comes to be treated, he comes to be cared, to not have any crisis. Is medicated, advised, oriented. [...] Our greatest desire, our greatest pleasure is when we can recover a patient. (ESA2)

The professional emphasized the commitment of the professionals so that the patients "recover". The absence of crises was understood as a fundamental point of recovery of the same, which in fact resulted from the institutional medicalization and subjection of the inmates, that is, the intervention that transforms people with some level of dangerousness into docile bodies.

The reports transcribed above indicate that the professionals believed in the positive conception about the treatment given to patients of the HCT. In the authors' conception, the "positive criticism" of the HCT's treatment comes from the alienating logic that dominates the minds of those who work in closed institutions and has as a parameter the degradation imposed on the inmates of other prison units.

The security measure, taken as a form of treatment, assumes a double system of protection established by justice, between it and the imposed punishment. To get rid of the unseemly role of punishing, the legal system uses an administrative device that gives another name to the execution of the sentence. Thus, there is a reassignment of the power to punish, which assumes the need to care for the subject, but does not distance itself from the power economy of the soul's torment. ${ }^{13}$

The above statements indicate the lack of knowledge of the workers about the National Mental Health Policy, which brought a new perspective to the Brazilian legal system in relation to the person with mental disorder, through Law no. 10,216 on April 6, 2001. This legislation lays down the protection and rights of persons with mental disorders and reformulates the mental health care model, thus expressing the principles of the Psychiatric Reform. ${ }^{14}$

If some workers considered the HCT as a treatment area, others placed them in the category of a prison institution, offering the prisoners the punitive and segregating interventions common to institutions of this nature.

\section{The HCT as a place of segregation and punishment}

Other professionals, with a divergent logic from those presented in previous reports, expressed the belief that treatment in HCT was not effective, as it does not bring any kind of benefit to the patients. The distance between professional and patient prevented the appropriate interaction for the conduct of therapeutic practices, as follows:
I think it affects negatively the treatment of the patient, because in the same way that he does not have a relationship with us, I don't think they have any among themselves, the psychiatrist with the social worker, the psychologist, get it? (ED2)

The professional reports, explicitly, his disbelief in the effectiveness of the treatment provided by the HCT. The existing conditions were closer to those of a prison environment, making the proposal for "recovery" of patients unfeasible. He also expressed the lack of involvement and involvement of the professionals with the inmates.

Sometimes we have a conduct towards the patient and the security staff has another, one opposing the other's speech. (EP2)

A professional reports that there is no single line of work, the institution has no treatment plan for patients. Each professional acts according to his own conceptions, without any type of guideline of the work. There are no team meetings or case discussions, the professionals do not talk about the behaviors with each patient, which makes it unfeasible to carry out a unique treatment for each patient.

There are no clinical meetings, case discussions, or evolution of the patient chart. Institutional objectives related to health are not met. The absence of dialogue causes an imbalance between the actions of professionals, who act in contradictory and sometimes incompatible ways.

Appropriating their principles and conceptions, often based on common sense, professionals demand from the patient what they consider necessary, framing it in a rigid model, in which difference is not admitted. Without understanding the patient's uniqueness, professionals cannot discuss their needs and conceive possibilities of treatment and articulation between the subject and the social. ${ }^{15}$

In the institution, there was no physical space to discuss issues experienced by workers or for the development of actions, which favored the formation of groups, by convenience. Consequently, no treatment plans were drawn up that would attend the uniqueness of the patients who were treated without planning the actions. ${ }^{16}$

The patients who are here, in addition to committing a crime, are mentally ill, have a severe mental illness and if you press with prison rules, prison dictatorship, marking according to operational procedure (OP), suicides begin to happen, problems, differences. This is a fact! What happened here a few years ago [...]. (ESA2)

We have an OP to follow. We that I talk about is the whole office, understand? According to the secretariat, there is an ongoing OP study for hospitals, with differentiated 
rules, because OP for penitentiary does not apply fully here. So, you have to have a differentiated OP for hospitals which are three, do you understand me? (ESA2)

Because it is linked to the penitentiary system, the institution adopts Operational Procedures - OPs of security common to prison units, but the rigidity of this and the entire security strategy were organized in the prison system. Therefore, they need to be adapted by the professionals, to be applied in the HCT.

In the United States, even the best prisons for criminals with mental disorders can not be considered hospitals. They function as prisons and in some cases are more restrictive and austere compared to ordinary prisons. In these institutions, the turnover rate is very high and the risk of suicide is much higher than in ordinary prisons. Small prisons can compensate for their lack of mental health treatment using local health services and emergency medical care. ${ }^{17}$

The speeches of the participants presented above highlight the inability of the mental hospitals for psychosocial resocialization, prevailing the paradigm of stigma. The theme will be presented and discussed below:

\section{The in(ability) of the legal mental hospitals for resocialization}

The proposal of the resocialization of the patients hospitalized in the HCT appeared in the speech of the workers, according to the expressions below:

The intention today is to return with these patients to society, afterfulfilling their sentence. (...) Our social worker left now, but she was always in touch (ENA1).

\section{[...] But I believe it is of the utmost importance to continue} in the process of re-socialization, once the prison system's proposal is to re-socialize, to return the person to social life with conditions to have social contact. I think the role of the hospital at this point is of paramount importance (ESA3)

At the time of data collection it was possible to observe that the institution was without professional of the social service. A professional from a prison unit was given, temporarily, one day a week to provide coverage. By non-participant observation, it was possible to infer that the social worker was not able to do anything, besides a bureaucratic service, nothing that could be compared to the practices of a social reinsertion work.

In the measures recommended in the Opinion on security measures and hospitals for custody and psychiatric treatment, ${ }^{18}$ semiannual reassessments of risk of violence are recommended, replacing the term "dangerousness", before the end of the security measure, so as to favor short hospitalizations and that family and social ties are not interrupted, as well as the reintegration of those without a network in the residential therapeutic services of Mental Health.
However, from the legal point of view, the person with a mental illness who commits a crime is not considered to be the author of the act, since he is incapable of distinguishing the unlawful nature of his own acts, therefore, unimpeachable. In this context, the law determines the acquittal, followed by application of Security Measure (MS). To the person who is criminally guilty applies a sentence and to those considered a socially dangerous a MS. Theoretically, sentences and MSs have distinct purposes, application conditions and modes of execution. The sentence is applied to those responsible for their acts and builds on the culpability of the offender. It is characterized as repressive penal sanctions, has a retributive character, with distressing intent and proportional to the gravity of the act committed. It does not focus on healing and because guilt rests on it, it aims at punishment. ${ }^{4}$

In theory, hospitalization focuses on the subject's treatment, without any punitive intent. It is an attempt to ensure treatment for the subject without causing him harm. As the dangerous state is directly related to mental health, it is assumed that it is not possible to calculate for sure the time required for its extinction, so that MS does not have predetermined duration time. However, what happens in practice in many cases is that the person is imprisoned in a life sentence. The stigma of the danger accompanies her requiring proof by the medical expert, of the cessation of her dangerousness, to obtain the suspension of the MS. Revocation of the measure will only occur if the person, one year after its release, has not shown signs of persisting of the danger. ${ }^{19}$

As in Brazil, in Greece, people not guilty due to insanity are also at a disadvantage when compared to convicted criminals or people hospitalized in psychiatric hospitals. The common criminal, when punished with loss of liberty for a certain period and like all individuals convicted in court, has the right to appeal and reduce his sentence in a higher court and perhaps be released from jail early, for good behavior, for example. While the individual not guilty by reason of insanity, he is at a disadvantage because he is kept interned for an indefinite period of time. In addition, you will only be allowed to leave the institution after a subjective evaluation by a judge, who will decide that the individual "is no longer dangerous". Professional who, by the way, has no psychiatric knowledge. ${ }^{20}$

Prisons are paradoxical for prisoners with conditions of mental illness, as they are "counter-therapeutic or toxic" and may exacerbate or trigger relapses. ${ }^{21}$

I have searched, sometimes even by listening to the radios, the jobs that we are trying to do here for resocialization. To invite people from society to come here. For example, we are marking our male and female square dance group, which we do here in the courtyard. I invite people from the community to attend. (...) I think the main work is the one of resocialization, with manual works, works with the psychiatrists. For example, when we make a forró for them, just as I have done on a carnival, the Christmas party and they presented a theater, because they were rehearsing a month preparing the play. While they are busy with the task, even the amount of medication decreases (EN3). 
The professional mentions that resocialization should start during the period of hospitalization. The few artistic-cultural initiatives that took place in the institutional space had the support of the patients, who were motivated and involved. When he said that even the medication was reduced, he inferred a therapeutic character to the activities developed.

It is important to stress the importance of psychotherapeutic treatment, workshops, and collective activities that stimulate the formation and strengthening of social ties. Practices that take into account the subjectivity of the patient should be promoted, aiming to reach beyond the control of symptoms. The workshops constitute a space that promotes potentialities and skills, allowing the patients involved to participate actively in their process of psychological and social rehabilitation. ${ }^{22}$

We had to have a transitional space where he still was not at his own risk and still had some protection from the state. I think this transition period, a sociological and spatial transition, including (ENA1).

(...) Each County would have to have its residence to receive those patients who already are with dangerousness ceased. (...) There are patients who have nothing, have no family, or the family does not accept. Then he gets confused and expects the state to find a solution. (...) They end up staying here, and it is better here than thrown in society without treatment without anything. (D3)

The authors of the present study propose that the Ministry of Justice invest in transitional therapeutic residences owned by HCT. In these, the patients who were fit, by the evaluation of the health technical team, would have the daily monitoring and supervision of a professional of the health team assigned to the institution, as a technical reference. In this period, patients would learn the activities of home care and management. If, after a year, the self-assessment and the evaluation of the reference technician indicated that they were able to live alone, they could be transferred to a therapeutic home in the municipality of origin if they could not return to their families. One of the authors of the study met this proposal at the São João de Deus Health House in Barcelos - Portugal, with residents of the psychiatric hospital. The program was successful in the process of deinstitutionalization and re-socialization of patients.

Through an evaluation, follow-up and post-hospitalization treatment, the patient will have the possibility to go back to the family, to form a family, to regulate their own life ... Take to the movies, take to the mall as we do with the children. We have to reeducate them to return to the life they left. Only for the good life, not for the bad side left behind. But the reality of our unit falls short. They are abandoned here. Of course there are those extreme cases where you can't do it. (EAS1)
In the case of $\mathrm{HCT}$, it is necessary to promote the continuity of access to mental health care, a service must necessarily have the following characteristics: not be stigmatizing and be flexible; offer repeated opportunities for engagement; Integrate mental health care and substance abuse; have information transfer mechanisms, allowing continuity of evaluation through health providers in each part of the criminal justice system; ensure that the priorities and strengths of the items above were worked on; and finally, to have initiatives articulated with the criminal justice services. ${ }^{23,24}$

In Brazil, the possibility of treating and caring for MS patients in an outpatient setting has been carried out through the work of professionals from the Care Program in accordance with the principles of the Brazilian Psychiatric Reform. ${ }^{25}$

In 2000, the General Court of Justice of Minas Gerais, Brazil, implemented the pilot project, in which the defendant or convicted person suffering from mental illness, with ongoing lawsuits in the criminal courts of the district of Belo Horizonte, was accompanied to perform mediation between treatment and the legal process, until their social reinsertion was possible. The project, initially called "Project for Interdisciplinary Follow-up to the Judiciary Patient" - PIF-JP, acts with the criminal judges establishing the connection with the public health network, before and after the sentence, from the beginning of the criminal process until the its completion, that is, at all stages. ${ }^{26}$

The PIF-JP team works to "secretariat" each patient in their needs, as a service that assists the decisions of the judiciary. To achieve the purposes of the program, it is necessary to partner with SUS mental health workers; of organizations; social and family entities, among others. In articulated work with the public mental health network, a unique and social therapeutic plan is constructed, revised whenever necessary, according to the momentary demands. ${ }^{15}$

Another successful experience was the Comprehensive Attention Program for the Mad Offender of Goiás - "PAILI". Following the basic principles advocated by the work of the General Court of Justice of Minas Gerais, the "PAILI" gained the autonomy of physicians and psychosocial teams from the open service units and the clinics that had agreements with SUS, to guide the treatment of patients in compliance with MS. ${ }^{25}$

The authors consider essential inter-institutional relations, that is, the interaction of HCT professionals with the judiciary and social assistance, in order to be negotiated the deinstitutionalization of many who are there, but who should receive treatment in community services.

A 13 to 20-year follow-up, depending on the sanction, of a cohort of mentally ill offenders in Sweden, showed that community supervision was more effective in terms of their ability to manage the risk of violent recidivism. Cases that deviate from the treatment plan should undergo compulsory relief that could restore adherence to the plan. The results also showed the need to consider treatment for psychoactive substance abuse as an important risk management intervention to reduce the risk of recurrence in violent crime..$^{27}$ 
The preventive or coping strategies of a phenomenon, which turn directly to individuals, seeing them as "risk" that they offer to society or to which they submit to, result in stigma and social segregation. ${ }^{28}$ In this sense, the authors consider that the hospitalization of MS sufferers does not contribute to the improvement of their psychic state, only punishes them for the offending act committed. These people should be considered vulnerable, as they express the potential for illness related to the individual living under a set of conditions. ${ }^{28}$

The vulnerability presents characteristics very different from the concept of risk, since it seeks to identify elements related to illness in more concrete and particular perspectives, trying to understand the mediations and relationships that determine them. ${ }^{28}$

This study has as limitation to be restricted to a HCT, although it is the only one still existing in the state of Minas Gerais. Therefore, it is not susceptible of generalizations. In this sense, the authors suggest that other studies be carried out in other Brazilian hospitals of custody and treatment.

\section{CONCLUSION AND IMPLICATIONS FOR PRACTICE}

It was perceived a contradiction in the ideology of the workers and of the operative institutional juridical system, since theoretically resocialization is placed as one of the main objectives of the institution, but in practice it is placed at the service of the punitive system of society. The professionals spoke of the "intention" of a rehabilitation project that should be put into practice, but that in reality are part of a machine of production of segregation and punishment. We did not see interventions that responded to the uniqueness of patients in MS, who are not prepared to return to social life, just as in prisons.

The "transition period" for those who are institutionalized becomes necessary, since institutionalization leads to the impossibility of acculturation. Thus, these people become untrained to live in society which makes them unable to meet and overcome, for some time, the demands of everyday life or the problems inherent in social life. These people need to be acculturated again.

Health, social assistance and justice professionals should monitor directly and individually those individuals who comply with HCT safety measures, through case management, so that they are not treated in this modality of closed institution, but may be re-socialized and cared for in the community health services of the Psychosocial Care Network (PSCN).

There are experiences such as the PAI PJ, from Minas Gerais, the Comprehensive Attention Program for the Insane Transgressor, from Goiás - Brazil, and the therapeutic residences, which have already been put into practice with success and that must be implemented by the Ministry of Justice, in joint action with the Ministry of Health, which would certainly humanize the interventions of the HCT to replace it, gradually.
The authors highlight the relevance of "a clinic made by many", which has an interdisciplinary team composed of doctors, nurses, judicial psychologists, legal social assistants, legal assistants and trainees in nursing and psychology, as it became clear that there was no multidisciplinary treatment approach in HCT and little interaction among team members. It is imperative that, for the evolution of the treatment, the elaboration of a therapeutic plan articulated by the interdisciplinary team, and that it is executed integrally and revalued periodically.

Nurses have a prominent role in the interdisciplinary team, since their professional activity presupposes a greater connection with patients. Thus, the authors suggest that this modality of institution has more than one nurse in its staff, so that with the nursing technicians in sufficient numbers, they are to provide the care and follow-up of the patients during their hospitalization and not the penitentiary agents.

\section{ACKNOWLEDGMENTS}

The Vice-Rectory of Research of the Federal University of Minas Gerais, for the financial support to the publication (Edital 02/2017 - Institutional program for the improvement of scientific production).

\section{REFERENCES}

1. Santos ALG, Farias FR, Pinto DS. Por uma sociedade sem hospitais de custódia e tratamento psiquiátrico. Hist Ciênc Saúde-Manguinhos [Internet]. 2015 Oct; [cited 2017 Jan 15]; 22(4):1215-30. Available from: http://www.scielo.br/pdf/hcsm/v22n4/0104-5970-hcsm-22-4-1215.pdf. DOI: 10.1590/S0104-59702015000400004

2. Santana AFFA. O manicômio judiciário e seus pacientes na visão dos trabalhadores: atenção à saúde e equipamento prisional [tese]. Belo Horizonte: Escola de Enfermagem, Universidade Federal de Minas Gerais; 2015. 170 p.

3. Carrara S. Crime e loucura: o aparecimento do manicômio judiciário na passagem do século. Rio de Janeiro: Eduerj; São Paulo: Edusp; 1998 $228 \mathrm{p}$.

4. Código Penal (BR). 39a ed. Saraiva. 2001.90 p. Available from: http:// www.oas.org/juridico/mla/pt/bra/pt_bra-int-text-cp.pdf

5. Yin RK. Estudo de Caso: Planejamento e Métodos. 5ª ed. Porto Alegre Bookman; 2015. 290 p.

6. Bardin L. Análise de Conteúdo. São Paulo: Edições 70; 2011. 280 p.

7. Santos ALG, Farias FR. Criação e extinção do primeiro Manicômio Judiciário do Brasil. Rev Latinoam Psicopat Fund [Internet]. 2014 Sep; [cited 2017 Jan 4]; 17(3):515-27. Available from: http://www. scielo.br/pdf/rlpf/v17n3/1415-4714-rlpf-17-03-00515.pdf. DOI: 10.1590/1415-4714.2014v17n3p515-9

8. Garcia MLT, Leal FX, Abreu CC. A política antidrogas brasileira: velhos dilemas. Psicol Soc [Internet]. 2008; [cited 2017 Jan 30]; 20(2):267-76. Available from: http://www.scielo.br/pdf/psoc/v20n2/a14v20n2.pdf. DOI: 10.1590/S0102-71822008000200014

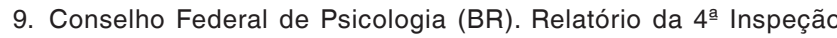
Nacional de Direitos Humanos: locais de internação para usuários de drogas. Conselho Federal de Psicologia. Brasília: Conselho Federal de Psicologia; 2011.200 p. [cited 2017 Jul 26]. Available from: http://site. cfp.org.br/wp-content/uploads/2012/03/2a_Edixo_relatorio_inspecao_ VERSxO_FINAL.pdf 
10. Fossi LB, Guareschi NMF. O modelo de tratamento das comunidades terapêuticas: práticas confessionais na conformação dos sujeitos. Estud Pesqui Psicol [Internet]. 2015; [cited 2016 Dec 10]; 15(1):94-115 Available from: $h$ ttp://pepsic.bvsalud.org/pdf/epp/v15n1/v15n1a07.pdf

11. Ibrahim E, Vilhena J. Manicômio judiciário: é possível ao louco-criminoso resistir? Psicol Ciênc Prof [Internet]. 2014; [cited 2017 Jan 12];34(4):87993. Available from: http://www.scielo.br/pdf/pcp/v34n4/1982-3703pcp-34-4-0879.pdf. DOI: 10.1590/1982-370001542013

12. Foucault M. A Genealogia e a História. In: Foucault M. Microfísica do Poder. Capítulo 2. 4⿳亠丷厂 ed. Rio de Janeiro: Graal; 1979. p. 15-38.

13. Foucault M. Vigiar e Punir: Nascimento da Prisão. $5^{\underline{a}}$ ed. Petrópolis: Vozes; $1987.288 \mathrm{p}$.

14. Lei no 10.216 , de 6 de abril de 2001 (BR). Dispõe sobre a proteção e os direitos das pessoas portadoras de transtornos mentais e redireciona o modelo assistencial em saúde mental. Brasília: Diário Oficial; 2001.

15. Santana AFFA, Alves M. Health professionals experiences in a judicial asylum and their view about the patients. J Nurs UFPE [Internet]. 2015 Sep; [cited 2017 Jan 28]; 9(Suppl. 8):9366-75. Available from: http://www. revista.ufpe.br/revistaenfermagem/index.php/revista/article/view/6673/ pdf_8629. DOI: 10.5205/reuol.6812-75590-1-ED.0908sup201505

16. Santana AFFA, Alves M. Realidade de um manicômio judiciário na visão de profissionais: do tratamento à segregação. Rev Min Enferm [Internet]. 2015b Jun; [cited 2017 Jan 7]; 19(2):133-41. Available from: http://www. reme.org.br/artigo/detalhes/1011. DOI: 10.5935/1415-2762.20150031

17. Felthous AR. Prisons and mental health: introductory editorial: hospitalizing mentally ill patients. Int J Law Psychiatry [Internet]. 2013; [cited 2017 Jan 12]; 36(3-4):185-7. Available from: https://www.ncbi. nlm.nih.gov/pubmed/23651702. DOI: 10.1016/j.jilp.2013.04.011

18. Ministério Público Federal (BR). Parecer sobre medidas de segurança e hospitais de custódia e tratamento psiquiátrico sob a perspectiva da lei no 10.216/2001. Brasília: Ministério Público Federal. 2011. 104 p. [cited $2017 \mathrm{Jul}$ 26]. Available from: http://pfdc.pgr.mpf.mp.br/temasde-atuacao/saude-mental/docs-publicacoes/parecer_medidas_ seguranca_web.pdf

19. Fontana-Rosa JC, Cohen C. Psicopatologia Forense na esfera penal. In: Cohen C, Ferraz FC, Segre M, orgs. Saúde Mental, Crime e Justiça. $2^{\mathrm{a}}$ ed. São Paulo: EDUSP; 2006. 284 p.

20. Douzenis $A$. The importance of the patients deemed not guilty by reason of insanity for the psychiatric reform. Psychiatriki [Internet]. $2016 \mathrm{Jul}-$ Sep; [cited 2017 Jan 21]; 27(3):165-8. Available from: https://www.ncbi. nlm.nih.gov/pubmed/27837570
21. Human Rights Watch. III-equipped: US Prisons and Offenders with Mental IIIness. 2003. 223 p. [cited 2017 Jul 26]. Available from: https:// www.hrw.org/reports/2003/usa1003/usa1003.pdf

22. Farias ID, Thofehrn MB, Andrade APM, Carvalho LA, Fernandes HN, Porto AR. Oficina terapêutica como expressão da subjetividade. SMAD Rev Eletrônica Saúde Mental Álcool Drog. [Internet]. 2016 JulSep; [cited 2017 Jan 28]; 12(3):147-53. Available from: http://pepsic. bvsalud.org/pdf/smad/v12n3/pt_03.pdf. DOI: 10.11606/issn.18066976. v12i3p147-153

23. Byng R, Quinn C, Sheaff R, Samele C, Duggan S, Harrison D, et al Cocoa: Care for offenders, continuity of access. London: National Institute for Health Research, Queen's Printer and Controller of HMSO 2012. 265 p. [cited 2017 Jul 26]. Available from: http://www.netscc. ac.uk/hsdr/files/project/SDO_FR_08-1713-210_V01.pdf

24. Forrester A, Exworthy T, Olumoroti O, Sessay M, Parrott J, Spencer SJ, et al. Variations in prison mental health services in England and Wales. Int J Law Psychiatry [Internet]. 2013; [cited 2017 Jan 29]; 36(3-4):32632. Available from: https://www.ncbi.nlm.nih.gov/pubmed/?term=Var ations+in+prison+mental+health+services+in+England+and+Wales. DOI: $10.1016 / j . j$.jlp.2013.04.007

25. Santana AFFA, Chianca TCM, Cardoso CS. Direito e saúde mental: percurso histórico com vistas à superação da exclusão. Psicol Rev [Internet]. 2011 Apr; [cited 2017 Jan 26]; 17(1):16-31. Available from: http://periodicos.pucminas.br/index.php/psicologiaemrevista/ article/view/P.1678-9563.2011v17n1p16. DOI: 10.5752/P.16789563.2011V17N1P16

26. Barros-Brisset F. Um dispositivo conector - relato da experiência do PAI-PJ/TJMG, uma política de atenção integral ao louco infrator, em Belo Horizonte. Rev Bras Crescimento Desenvolv Hum [Internet]. 2010 [cited 2017 Jan 25]; 20(1):116-28. Available from: http://pepsic.bvsalud. org/scielo.php?script=sci_arttext\&pid=S0104-12822010000100016. DOI: 10.7322/jhgd.19951

27. Lund C, Hofvander B, Forsman A, Anckarsäter H, Nilsson T. Violent criminal recidivism in mentally disordered offenders: a follow-up study of 13-20 years through different sanctions. Int J Law Psychiatry [Internet] 2013; [cited 2017 Jan 28]; 36(3-4):250-7. Available from: https://www. ncbi.nlm.nih.gov/pubmed/?term=Violent+criminal+recidivism+in+menta $\| y$ +disordered+offenders $\% 3 \mathrm{~A}+\mathrm{a}+$ follow-up+study+of $+13 \%$ E2\%80\%93 20+years+through+different+sanctions. DOI: $10.1016 /$ j.j.jp.2013.04.015.

28. Gama CAP, Campos RTO, Ferrer AL. Saúde mental e vulnerabilidade social: a direção do tratamento. Rev Latinoam Psicopatol Fundam [Internet]. 2014; [cited 2017 Mar 25]; 17(1):69-84. Available from: http:// www.scielo.br/pdf/rlpf/v17n1/v17n1a06.pdf 